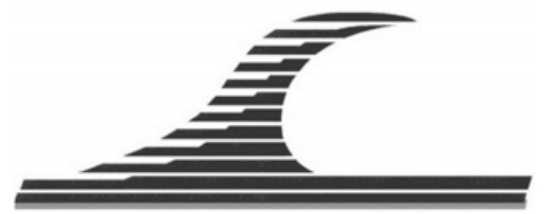

\title{
Modeling the hydrodynamic functioning of the mouth of the Bandama River, Grand-Lahou, Côte d'Ivoire
}

\author{
Kouakou Lazare KOUASSI ${ }^{1}$, Kouakou Séraphin KONAN ${ }^{1}$, \\ Martin SANCHEZ ${ }^{2}$, Kouamé AKA ${ }^{3}$
}

1. Centre de Recherche en Ecologie, Université Jean Lorougnon Guédé, 08 BP 109 Abidjan 08, Côte d'Ivoire.

k_lazare@yahoo.fr

2. Laboratoire de Planétologie et Géodynamique, UMR CNRS 6112, Université de Nantes, 2 rue de la Houssinière, 44322 Nantes, France. martin.sanchez@univ-nantes.fr

3. Université Félix-Houphouët-Boigny, Abidjan, Côte d’Ivoire. akaraphael@yahoo.fr

\begin{abstract}
:
Coastal erosion is a real threat on the Ivorian coast and particularly at the mouth of the Bandama River. Hydrosedimentary dynamics led to the relocation of the city of GrandLahou to the northern part of this region in the 1970s. Erosion not only modifies the coastline but also causes migration from the mouth of the Bandama River, destroying homes and plantations. This study, based on a 2D hydrodynamic model, using Mike 21 HD software, reconstructed the flow in the Grand-Lahou estuary. The strongest currents are located at the mouth and particularly in the pass. During low water periods, flow currents reach $1.4 \mathrm{~m} / \mathrm{s}$ in the channel, while during high water periods, high flows tend to block flow currents and intensify ebb currents. Current velocities reach $1.8 \mathrm{~m} / \mathrm{s}$ in the pass during ebb and are reduced to $0.35 \mathrm{~m} / \mathrm{s}$ in the flow.
\end{abstract}

Translated version of a paper in French

(DOI reference: https://doi.org/10.5150/jngcgc.2016.025), presented in the JNGCGC (Journées Nationales Génie Côtier Génie Civil), edition 14, 29 June - $1^{\text {st }}$ July, 2016, Toulon, France. Received 29 April 2019, accepted 15 May 2019, available online 27 May 2019.

How to cite this paper:

KOUASSI K.L., KONAN K.S., SANCHEZ M., AKA K. (2019). Modeling the hydrodynamic functioning of the mouth of the Bandama River, Grand-Lahou, Côte d'Ivoire. Revue Paralia, Vol. 12, pp n02.1-n02.10. DOI: https://doi.org/10.5150/revue-paralia.2019.n02 


\section{Introduction}

The Grand-Lahou estuary, a meeting place between the Bandama River, the Boubo River, the Grand-Lahou lagoon system and the Atlantic Ocean, represents, through its ecological and environmental diversity, an important source of subsistence and a source of income for the local populations whose main economic activity is traditional fishing (KONAN et al., 2013). The Grand-Lahou estuary is subject to sedimentary phenomena that result in changes in the morphology of the estuary and the migration of the pass from east to west (WOGNIN et al., 2008) and the significant variation in the physicochemical parameters of water bodies (KONAN et al., 2009). The water depths in the lagoon are generally low, which makes navigation quite difficult.

Fishing, which formerly occupied more than $60 \%$ of the population's activities, is declining and the population of Grand Lahou is therefore becoming more impoverished (ECOUTIN et al., 1994).

In order to restore vitality to the economy of the Grand-Lahou region, the Ivorian government has built a fishing school in Grand-Lahou with a port of application and boats for practical activities in inland and marine waters. However, the fishing school boats cannot access the sea because the pass remains unseaworthy.

To enable vessels to connect the port and the sea, a project is being considered to build a channel linking the port of application of the school of fishing to the sea.

To address hydrosedimentary problems such as those occurring in the Grand-Lahou lagoon system, several research projects are developing numerical models that have great advantages in understanding and managing the physical processes related to flow dynamics and sediment transport (UDDIN et al., 2014 ; CHHETRI et al., 2016 ; MARFAI et al., 2016).

To support the construction project for the Grand-Lahou channel, this study aims to model the hydrodynamic functioning of the mouth of the Bandama River and the Grand-Lahou lagoon system. This study is based on the numerical simulation of the currentology and propagation of the wave.

\section{Site and methods}

\subsection{Study site}

The Grand-Lahou estuary zone is located at latitudes $4^{\circ} 26$ and $5^{\circ} 20$ North and between longitudes $4^{\circ} 20$ and $5^{\circ} 20$ West. The Grand-Lahou lagoon system is mainly influenced by the Atlantic Ocean and the Bandama River (Figure 1).

The Grand-Lahou lagoon system consists of the Niouzoumou, Tadjo, Mackey and Tagba lagoons. The Tagba lagoon is the only outlet at sea of this lagoon system. 


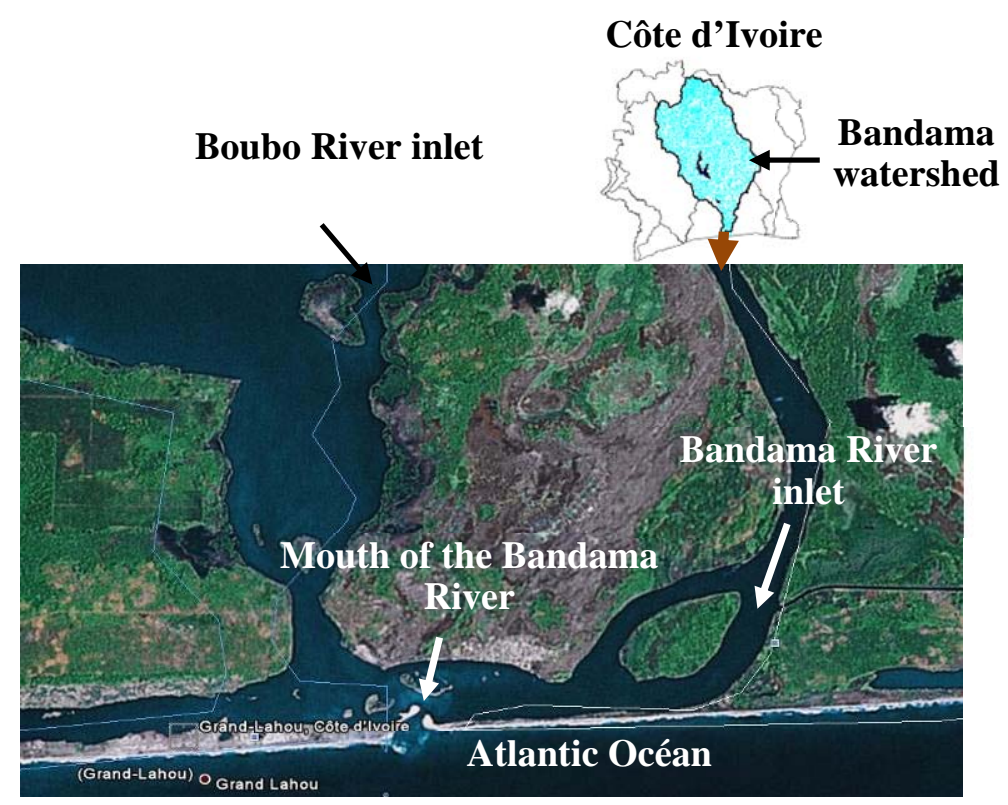

Figure 1. Location of the Grand-Lahou estuary area.

The climate of the Grand-Lahou region is equatorial, characterized by a large dry season from December to March, a large rainy season from April to July, a small dry season from August to September and a small rainy season from October to November. The hydrology of the estuary is essentially under the influence of the Bandama River regimes dominated by the tropical transitional regime of the northern watershed due to its elongated shape, coastal streams and marine seasons. The Bandama River is characterized upon arrival in the lagoon by a first flood between July and August (average flow of about $250 \mathrm{~m}^{3} / \mathrm{s}$ ), a maximum flood in October (average flow of about $750 \mathrm{~m}^{3} / \mathrm{s}$ ), and a low water period between March and April (average flow of about 75 $\left.\mathrm{m}^{3} / \mathrm{s}\right)$.

Sediment dynamics at the mouth of the Bandama River result in erosion and migration of the pass from east to west. Similarly, there are navigation problems due to the shallows (WOGNIN et al., 2008).

\subsection{Methods}

\subsubsection{Data acquisition}

The survey area is located between 04 ${ }^{\circ} 58^{\prime} 37^{\prime \prime}$ and $05^{\circ} 01^{\prime} 17^{\prime \prime}$ West longitude and $05^{\circ} 07^{\prime} 04^{\prime \prime}$ and $05^{\circ} 09^{\prime} 19^{\prime \prime}$ North latitude, representing an area of $5 \mathrm{~km}^{2}$ of water and 1 $\mathrm{km}^{2}$ on land.

A granulometric analysis was undertaken to assess sedimentary facies.

The flows of the Bandama River and the Boubo River were obtained from the Water Direction of the Ministry of Economic Infrastructure of Côte d'Ivoire. The river flows 
were observed for 64 years (1954-2018) at Tiassalé, a hydrometric station located about $100 \mathrm{~km}$ from the mouth of Grand-Lahou and representing more than $97 \%$ of the total area of the Bandama catchment. This station is not affected by the effects of the dynamic coastal tide. The rainfall data were acquired from the Aeronautical and Meteorological Exploitation and Development Company (SODEXAM). Wave and wind data were obtained from the United Kingdom Meteorological Office (UKMO) at the grid point of the UKMO grid $\left(004.72^{\circ} \mathrm{N}-005.42^{\circ} \mathrm{W}\right)$ located approximately $65 \mathrm{~km}$ southwest of Grand-Lahou.

Tides were measured during the campaigns conducted in January 2011 and JanuaryFebruary 2012 by DRAG AFRIK SA at the mouth of the Bandama River. In addition, due to the inadequacy of these tidal data, water level variations were extracted from the global Danish Hydraulic Institute model.

Current measurements were made using an Acoustic Doppler Current Profiler, Workhorse Rio Grande current meter type. Measurements were made on four (4) radials (Figure 2).

For each of the four radials (R1R2, R3R4, R5R6 and R7R8) a low tide and a high tide gauging was carried out from June 29 to July 1, 2012. The data obtained from the gauging are the average vertical current velocities, the average velocity and the total flow rate in the section.

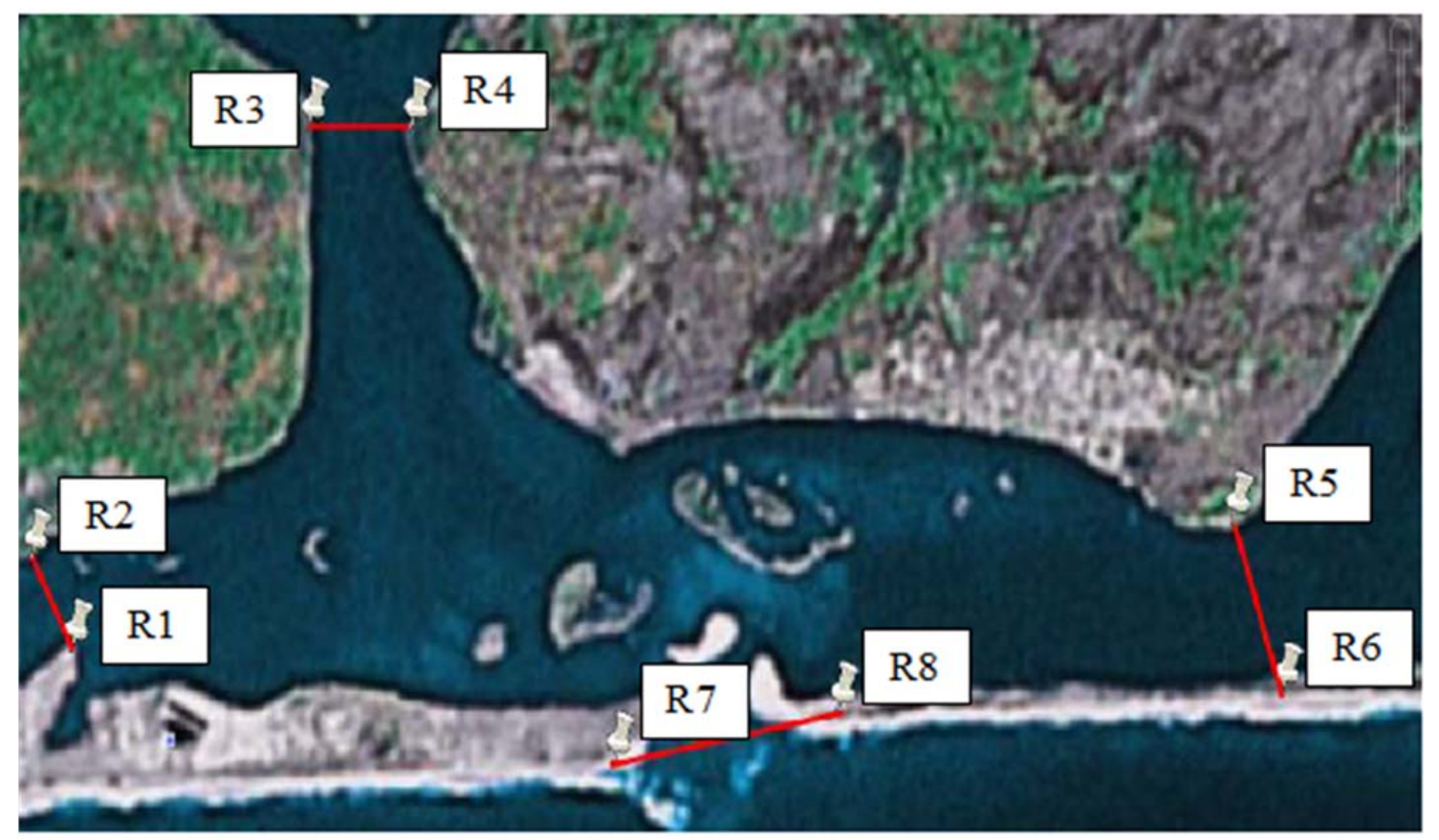

Figure 2. Position of the current measuring radials at the mouth of the Bandama. 


\subsubsection{Hydrodynamic modeling}

The hydrodynamic model was created using Mike 21 HD software. This solves the partial differential equations governing the problem, namely, the continuity equation and the equations for the conservation of mass and momentum integrated over the vertical (KOUASSI et al., 2013).

The mesh is composed of unstructured triangular elements, allowing the resolution of the model to be refined in areas of interest.

\subsubsection{Forcing conditions and model configuration}

The tide in the Atlantic Ocean and the flow of the Bandama River are the main forcing parameters in this hydrodynamic model.

The relevant calibration parameters in this study are the friction on the bottom and the flow of the Bandama River. A flow rate of $220 \mathrm{~m}^{3} / \mathrm{s}$ from the Bandama River was used for the calibration period from June 30 to July 1, 2012; the period corresponding to the flow and current velocity measurement campaign.

A Manning roughness coefficient of $32\left(\mathrm{~m}^{1 / 3} / \mathrm{s}\right)$, on average, was used on the whole model except for the entrance to the Tagba lagoon where a Manning coefficient of 10 was imposed because of the presence of mud.

\section{Results}

\subsection{Bathymetry and mesh size}

The mesh size has been adjusted according to the morphology of the bottoms and the desired precision. Thus, the mesh size varies from $10 \mathrm{~m}$ at the mouth to $1000 \mathrm{~m}$ offshore (Figure 3).

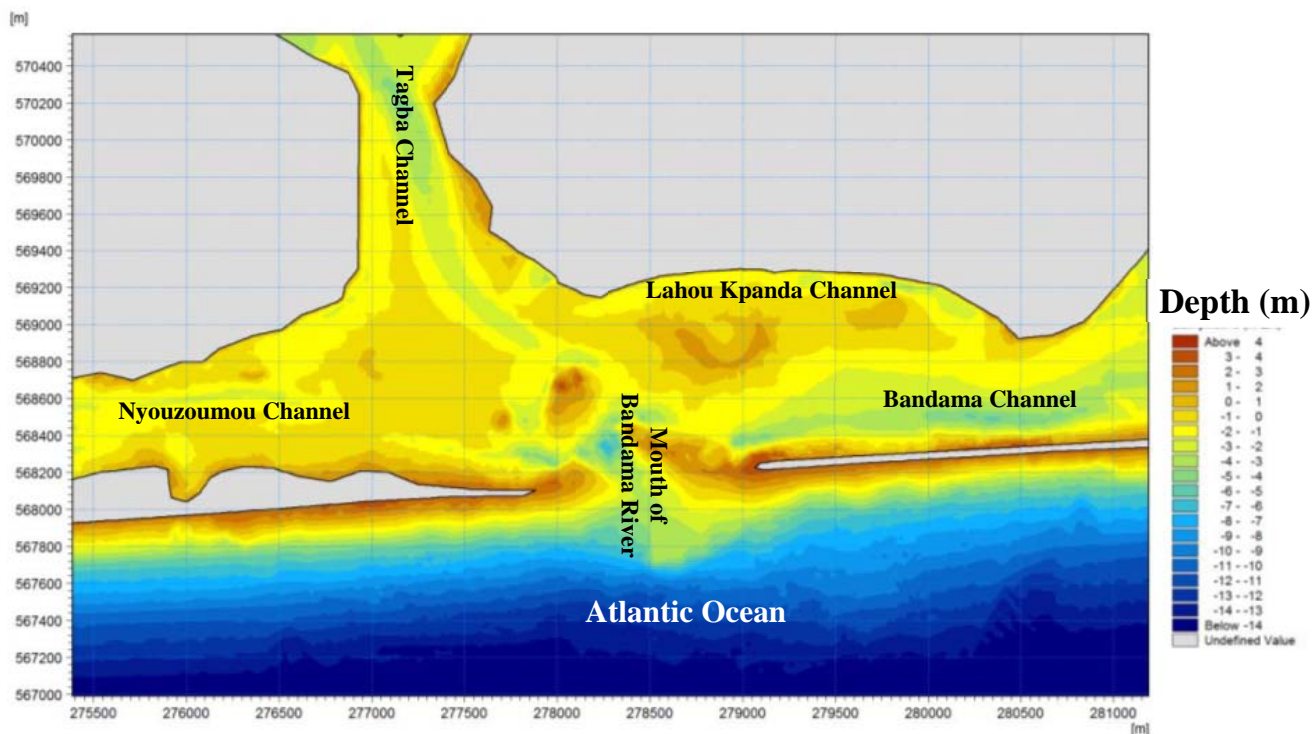

Figure 3. Bathymetry of the mouth of the Bandama River (2010). 


\subsection{Hydrodynamic model}

Flow dynamics in Grand-Lahou Lagoon Bay were assessed over a tidal cycle using a Bandama River flow of $220 \mathrm{~m}^{3} / \mathrm{s}$ for model calibration.

The tide in Grand-Lahou is of the semi-diurnal type (12h $25 \mathrm{mn}$ period) with high diurnal inequality. It is of the micro tidal type with a spring tidal range of about $1.4 \mathrm{~m}$ and a dead tidal range of about $0.6 \mathrm{~m}$. Two high tides of relatively close levels are observed every day and two low tides of different levels of about $0.4 \mathrm{~m}$ are also observed.

The average water level off Grand-Lahou is about $+0.78 \mathrm{~m} \mathrm{CM}$. The average elevation in the lagoon bay is about $10 \mathrm{~cm}$ above the average level in the coastal zone. The tidal curves have a generally symmetrical appearance with equal flow and ebb times (Figure 4).

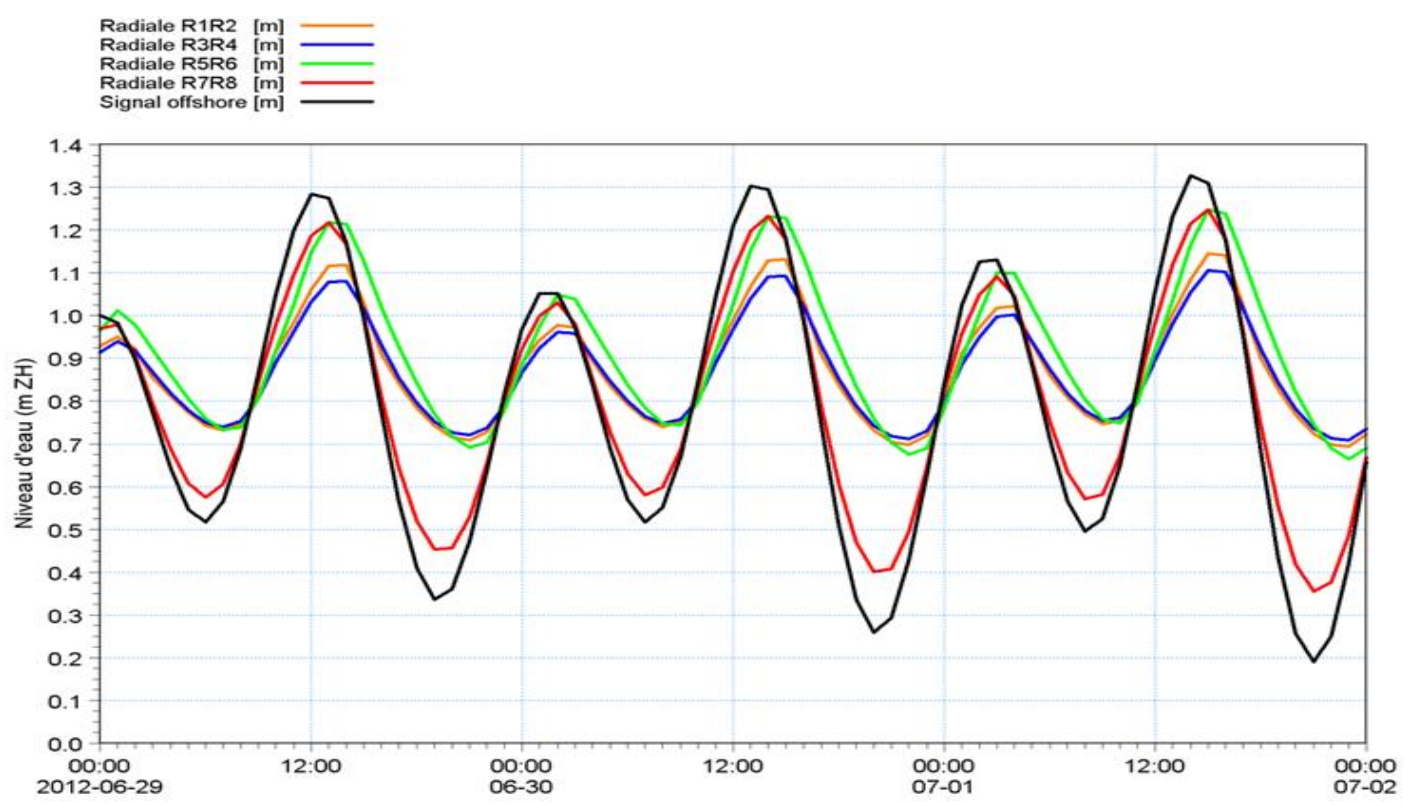

Figure 4. Water levels modelled in lagoon bay and off Grand-Lahou.

Under the effect of tides, the variation in water level is accompanied by a change in the direction of water flow. Flow is upstream to downstream during ebb and downstream to upstream during flow periods. Figure 5 shows an example of a result of simulating vertically averaged speeds.

Within the lagoon, the strongest currents are located at the mouth, in the pass and on either side of the central islet.

On each radial, a simulation of the instantaneous flows integrated into the section was carried out (Figure 6; negative flows represent the flows leaving the lagoon). 


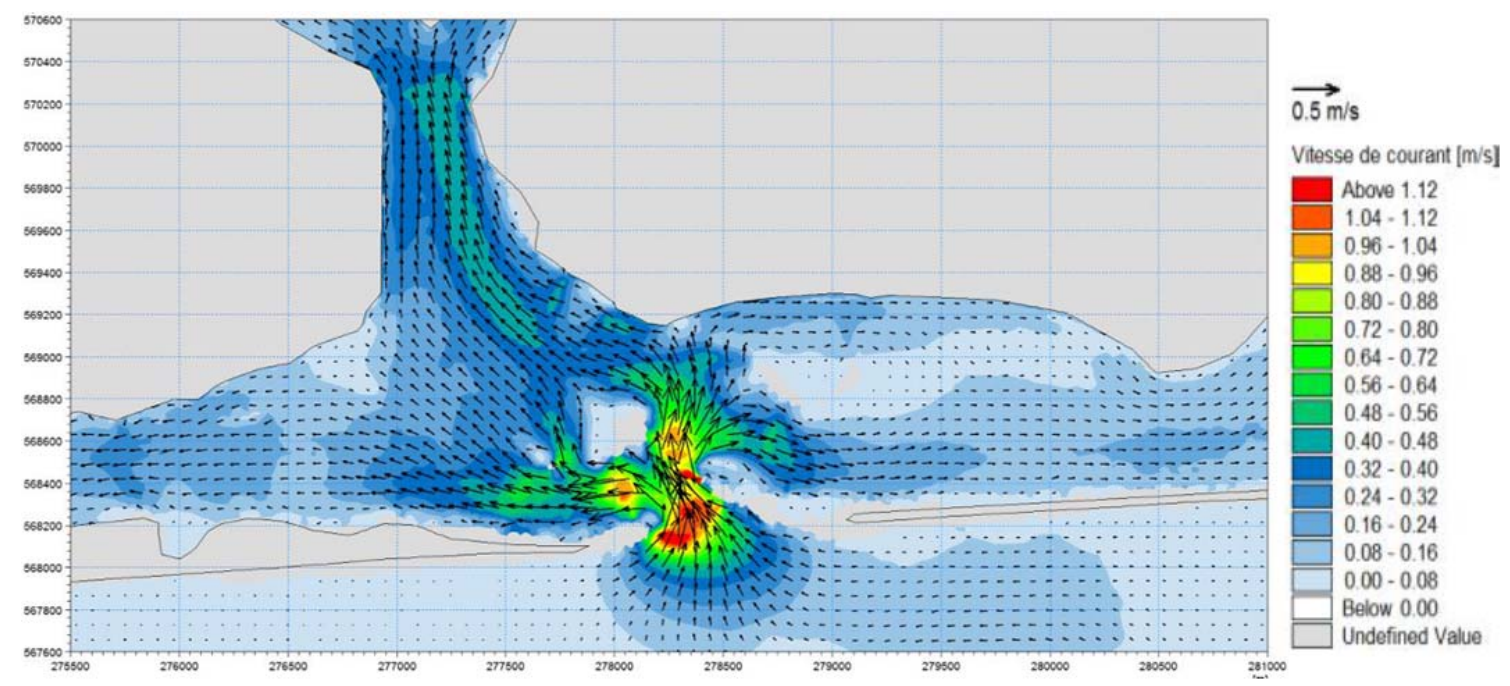

Figure 5. Flow field modeled as of June 30, 2012, flow period, 12:00.

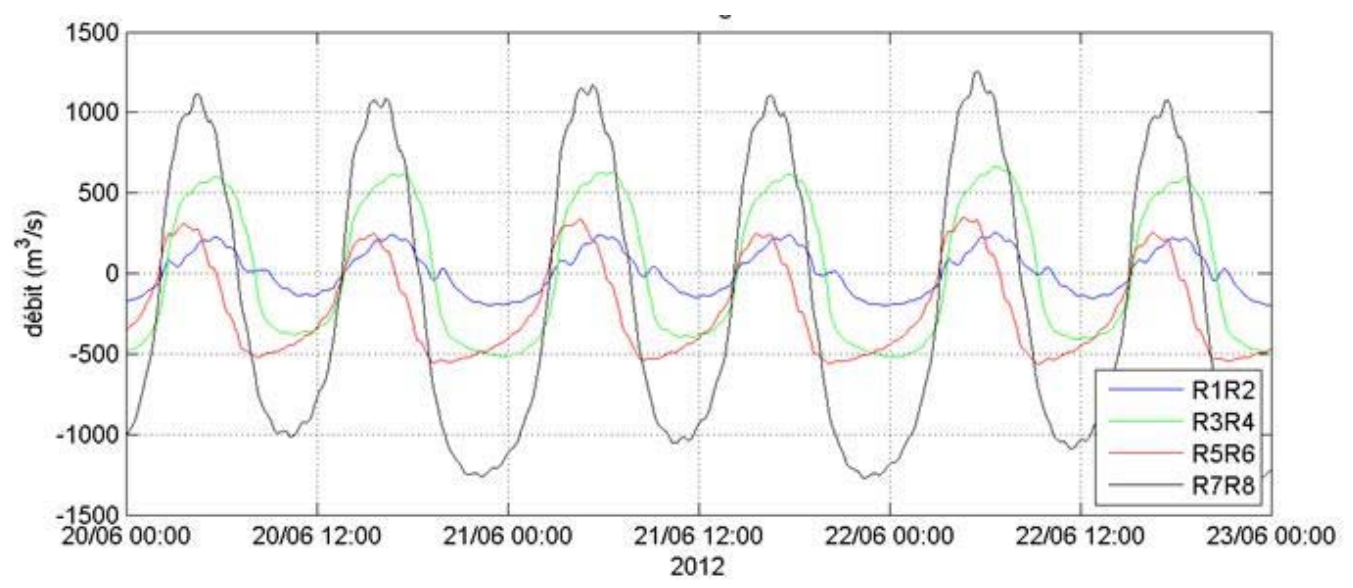

Figure 6. Water levels modelled in lagoon bay and off Grand-Lahou

A comparison of the measured and modelled flow values was carried out to validate the results. Since the reproduction of flows generally appears to be in good consistency with the measured data, the hydrodynamic model was used to simulate the period from June 12 to July 2, 2012, with the following flow conditions: stretching (Bandama 75 $\mathrm{m}^{3} / \mathrm{s}$; Boubo $0 \mathrm{~m}^{3} / \mathrm{s}$ ), first flood (Bandama $220 \mathrm{~m}^{3} / \mathrm{s}$; Boubo $0 \mathrm{~m}^{3} / \mathrm{s}$ ), second flood (Bandama $750 \mathrm{~m}^{3} / \mathrm{s}$; Boubo $20 \mathrm{~m}^{3} / \mathrm{s}$ ), maximum flood (Bandama $1500 \mathrm{~m}^{3} / \mathrm{s}$; Boubo 20 $\mathrm{m}^{3} / \mathrm{s}$ ). Figures 7 and 8 illustrate the distribution of currents in the lagoon at flow for Bandama flows of 75 and $750 \mathrm{~m}^{3} / \mathrm{s}$. During low water periods, flow currents reach 1.4 $\mathrm{m} / \mathrm{s}$ at the mouth and $0.4 \mathrm{~m} / \mathrm{s}$ in the Tagba channel. On the other hand, in flood periods, high flows tend to block flow currents and intensify ebb currents. The western sector (towards the Nyouzoumou lagoon) is less influenced by the tide and flows of the Bandama. Most of the lagoon's volume seems to flow through the Tagba Channel. 


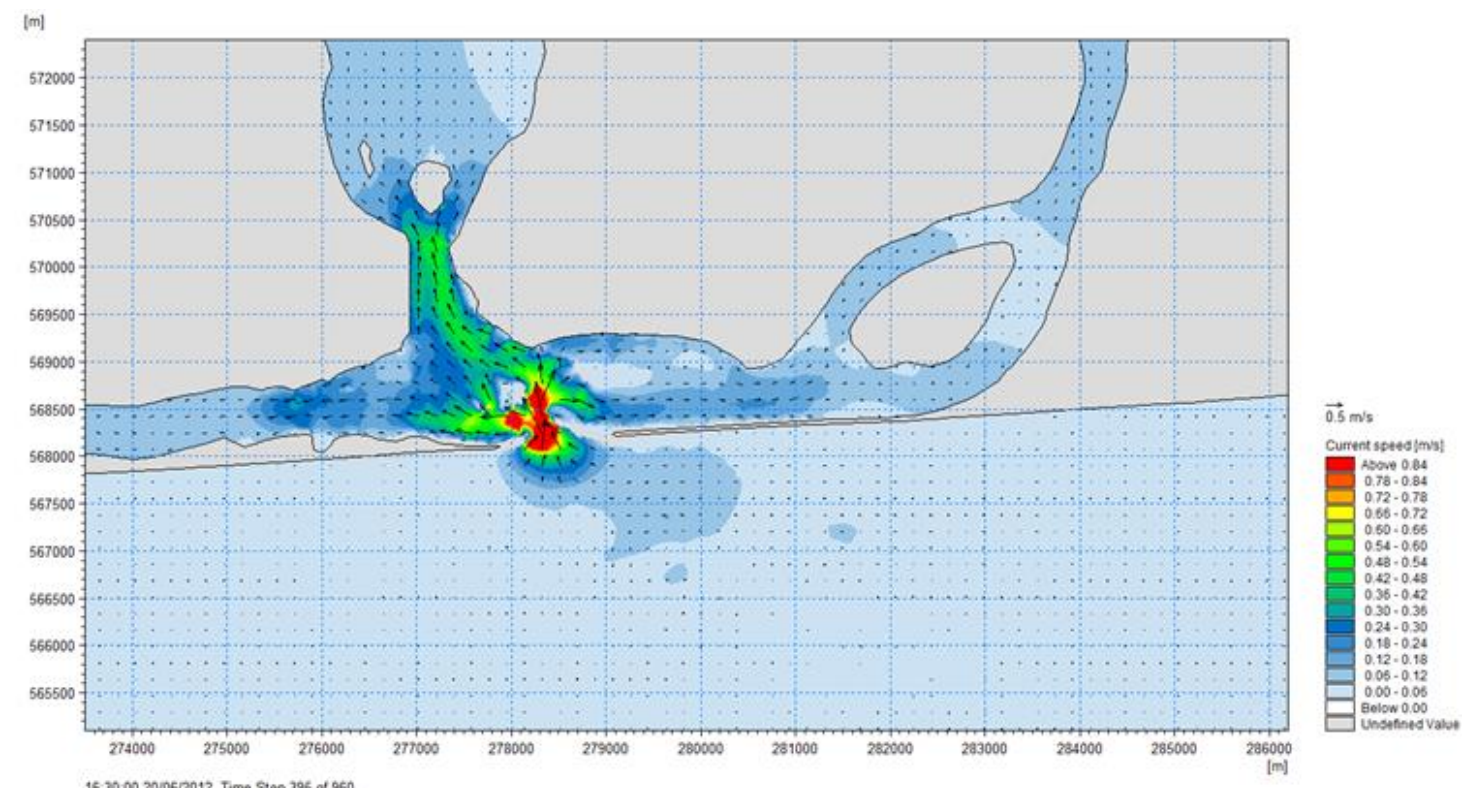

Figure 7. Flow field modelled in low water (75 $\left.\mathrm{m}^{3} / \mathrm{s}\right)$ during the flow (20/06/2012).

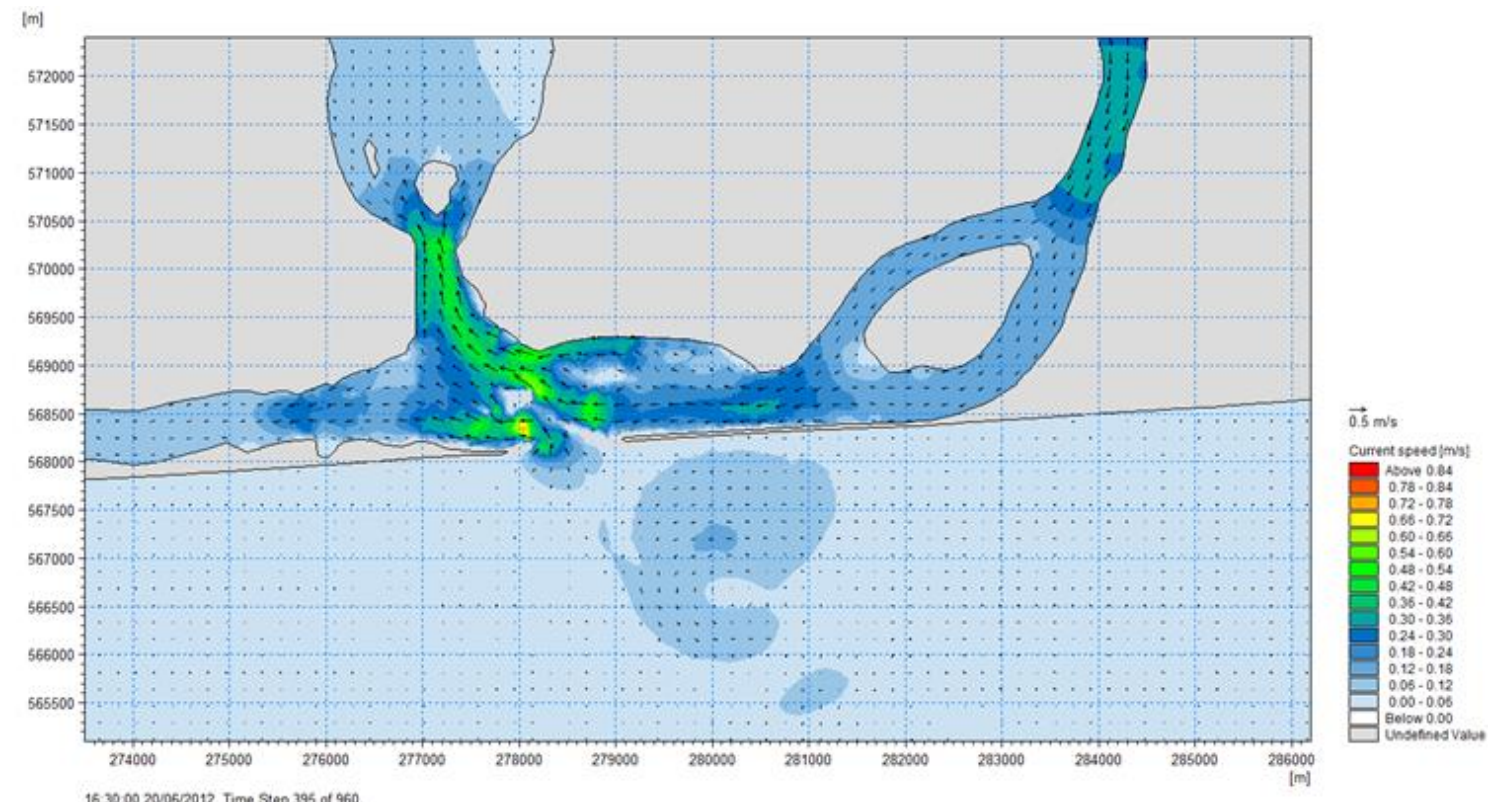

Figure 8. Flow field modelled as an average flood $\left(750 \mathrm{~m}^{3} / \mathrm{s}\right)$ during the flow (20/06/2012).

\section{Discussion}

Hydrodynamic phenomena at the mouth of the Bandama River are influenced by the Bandama River, the Boubo River, the Grand-Lahou lagoon system and the Atlantic Ocean. The dynamic of the environment is mainly marked by the Bandama flows and oceanic flows. According to WOGNIN et al. (2008), the tidal dynamics in the Bandama estuary would create a nodal point, an accumulation zone for suspended particles, 
whose position varies according to the Bandama's flow. At high flow rates, the turbid plume is expelled at sea, with a tendency to evacuate eastward, due to the orientation of ebb currents in the pass and currents on the continental shelf.

In Grand-Lahou, despite the migration of the mouth of the Bandama River due to hydro-sedimentary movements and coastal drift, the mouth remains open unlike the mouth of the Comoé River as reported by ADOPO et al. (2008). This may be due to the fact that the Bandama's flows are relatively sufficient to enter the Atlantic Ocean during ebb and flow periods and especially during the river's floods.

The study of sediment transport, with a good database, will provide a better understanding of the functioning of the Grand-Lahou estuary, which is undergoing westward migration according to WOGNIN (2008). Indeed, studies, and in particular hydrodynamic models and sediment transport models, make it possible to understand the hydrosedimentary functioning of hydrosystems and to guarantee the success of projects and the protection of the environment (AL-RABAI'AH, 2010; UDDIN et al, 2014; KANG \& YEO, 2015; CHHETRI et al., 2016).

\section{Conclusion}

The hydrodynamic model carried out at the mouth of the Bandama River shows that, within the lagoon, the strongest currents are located at the mouth, in the pass and on either side of the central islet. Flood and ebb currents are also intense in the Tagba lagoon channel, through which the largest volumes of water flow.

The western sector (towards the Nyouzoumou lagoon) is less influenced by the Bandama tide and flows; flows remain low due to the presence of a small canal that reduces traffic in this sector.

\section{Acknowledgements}

We sincerely thank the Ministry of Technical Education and Vocational Training of the Côte d'Ivoire for funding this study. The realization of this model was supported by the DHI Group whom we would like to thank for their contribution to our work.

\section{References}

ADOPO K.L., KOUASSI K.L., WOGNIN A. V.I., MONDE S., MÉLÈDJE N. H., AKA K. (2008). Characterization of the sediments and morphology of the Comoé river mouth (Grand-Bassam, Côte d'Ivoire). Revue Paralia, Vol. 1, pp 2.1-2.10. https://doi.org/10.5150/revue-paralia.2008.002

AL-RABAI'AH H. (2010). Transport of Suspended Solids in Dammam (Saudi Arabia) Coastal Areas: Fish Market Works. Journal Water Resource and Protection, Vol. 2, pp 540-544. https://doi.org/10.4236/jwarp.2010.26061 
CHHETRI A., KAYASTHA R.B., SHRESTHA A. (2016). Assessment of Sediment Load of Langtang River in Rasuwa District, Nepal. Journal of Water Resource and Protection, Vol.8, pp 84-92. https://doi.org/10.4236/jwarp.2016.81007

ECOUTIN J.M., DURAND J.R., LAE R., HIÉ J.P. (1994). L'exploitation des stocks, In environnement des ressources aquatiques de Côte d'Ivoire, les milieux lagunaires, Tome II. pp 339-444.

KANG J., YEO H. (2015). Survey and Analysis of the Sediment Transport for River Restoration: The Case of the Mangyeong River. Open Journal of Civil Engineering, Vol. 5, pp 399-411. https://doi.org/10.4236/ojce.2015.54040

KONAN K.S., KOUASSI A.M, ADINGRA A.A., GNAKRI D. (2009). Spatial and temporal variation of fecal contamination indicators in Graand-Lahou lagoon, Côte d'Ivoire. Journal of Applied Biosciences, Vol. 23, pp 1422-1435.

KONAN K.S., KOUASSI K.L., KOUAMÉ K.I., KOUASSI A.M., GNAKRI D. (2013). Hydrologie et hydrochimie des eaux dans la zone de construction du chenal du port de pêche de Grand-Lahou, Côte d'Ivoire. Int. J. Biol. Chem. Sci., Vol. 7(2), pp 819-831. https://doi.org/10.4314/ijbcs.v7i2.37

KOUASSI K.L., KOUAMÉ K.I., KONAN K.S., SANCHEZ-ANGULO M., DEMÉ M., MÉLÈDJE N.H. (2013). Two-Dimensional Numerical Simulation of the HydroSedimentary Phenomena in Lake Taabo, Côte d'Ivoire. Water Resources Management, Vol. 27, N¹2, pp 4379-4394. https://doi.org/10.1007/s11269-013-0417-x

KOUASSI K. L., DEME M., KONAN K. S., YAHIRI B. P., KONÉ D., SANCHEZ M., AKA. K. (2016). Modélisation du fonctionnement hydrodynamique de l'embouchure du fleuve Bandama, Grand-Lahou, Côte d'Ivoire. XIV èmes Journées Nationales Génie Côtier - Génie Civil, Toulon, pp 219-228. https://doi.org/10.5150/jngcgc.2016.025

MARFAI M.A., TYAS D.W., NUGRAHA I., FITRIATUL'ULYA A., RIASASI W. (2016). The Morphodynamics of Wulan Delta and Its Impacts on the Coastal Community in Wedung Subdistrict, Demak Regency, Indonesia. Journal of Environmental Protection, Vol. 7, pp 60-71. https://doi.org/10.4236/jep.2016.71006

UDDIN M., BIN ALAM J., KHAN Z.H., JAHID HASAN G.M., RAHMAN T. (2014). Two Dimensional Hydrodynamic Modelling of Northern Bay of Bengal Coastal Waters. Computational Water, Energy, and Environmental Engineering, Vol. 3, pp 140-151. https://doi.org/10.4236/cweee.2014.34015

WOGNIN V., MONDE S., COULIBALY A., KOUASSI K.L., ADOPO L., AFFIAN K., AKA K. (2008). Waters Model Circulation in the Estuary of Bandama. Rivers Flows and Tide condition's Incidence. European Journal of Scientific Research, Vol. 19(2), pp 304-314. 